(C) 2018 by T. Godlewski. This is an open access article distributed under the Creative Commons Attribution-NonCommercial-NoDerivs license (http://creativecommons.org/licenses/by-nc-nd/3.0/)

\title{
EVALUATION OF STIFFNESS DEGRADATION CURVES FROM IN SITU TESTS IN VARIOUS SOIL TYPES
}

\section{T. GODLEWSKI ${ }^{1}$}

Increasingly complex design systems require an individual approach when determining the necessary design parameters. As soils are characterized by strong strain-dependent nonlinearity, test methods used to characterize the subsoil should be carefully selected, in terms of their "sensitivity" as well as suitability for the analyzed type of problem. When direct measurements are not available, while design calculation models require specific parameters, indirect parameter estimation may be used. This approach requires calibration and validation of empirical correlations, based on well documented database of tests and case studies. One of the parameters often used, when analyzing soil-structure interaction problems, is the shear stiffness of the soil and its strain-dependent degradation. The aim of the article is to present the procedure for description and evaluation of soil stiffness based on field tests (CPTU, DMT and SDMT) and a large number of reference curves obtained from laboratory tests (TRX) for selected soil types. On the basis of the given algorithm, it is possible to obtain a stiffness module $\mathrm{G}_{0}$ value at any level of deformation, based on in-situ tests.

Keywords: soil stiffness, in situ tests, reference stiffness degradation curve, seismic dilatometer; overconsolidated soils.

\footnotetext{
${ }^{1}$ DSc., Eng., Building Research Institute, Building Structures, Geotechnics and Concrete Department, ul. Ksawerów 21, 02-656 Warsaw, Poland, e-mail: t.godlewski@itb.pl
} 


\section{INTRODUCTION}

Design of foundations and geotechnical structures requires obtaining proper parameters characterizing the subsoil [4], [11], [29], [39], [45], [55]. These parameters should be sufficiently reliable, therefore, obtained using methods that were properly validated or calibrated in local conditions [5], [11], [17], [51], [60]. The field testing methods have a very important role to play in this regard [24], [51]. Significant progress has been made in recent decades in regard to the equipment, automation, advancement in measurement registration and interpretation. As designers often use semi-empirical approaches, the results of these tests are often expected in geotechnical documentations. In recent years, new developments are mostly focused on implementation of geophysics in the measurements in order to measure shear wave velocities in the subsoil [14], [19], [35]. This offers a chance to make an estimate concerning the stiffness of the subsoil in the entire range of strain-dependent stiffness degradation. In order to ensure the safety and rational design for civil engineering structures, proper estimation of geotechnical parameters is necessary when analyzing soil-structure interaction [54]. When quantitatively estimating the value of deformation modulus of the soil, the choice should depend on the expected behavior of the structure. It means that this modulus should correspond to the stress-strain range of particular structure together with possible dynamic loads [3], [16], [35]. The discovery that the deformation modulus is highly non-linear in small deformations range $\left(10^{-6} \div 10^{-3} \%\right)$ was a large step forward in soil mechanics [3], [9], [25], [36]. Testing methods that allow to determine the values of modulus in this range are classified as advanced, where often the measurements of seismic waves are used. The fact that these methods of stiffness parameters determination are useful was confirmed by back analysis on constructed structures (for example: deep excavations) [4], [16], [38], [39], [45], [55] where moduli from geophysical methods were higher than the values provided in standards or those determined by classical methods. Soil stiffness, at small strains, is a relevant parameter in solving boundary value problems such as: response of soil deposits to earthquakes or dynamic interaction between soils and foundations [24]. However, it has been pointed out by many researchers that the strain level which often occurs in geotechnical problems is quite small even under the static loading condition and in the case of conventional foundations [25]. 


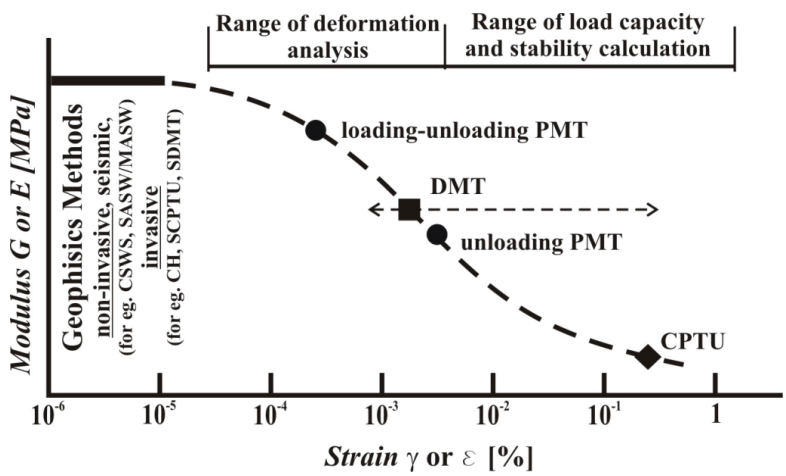

Fig. 1. Strain-dependent non-linearity of shear stiffness modulus in light of strain-levels associated with different structure-types and testing methods (modified [19] after [1]).

In complex loading conditions, when the subsoil can work at different strain-levels, the behavior over the entire stiffness degradation curve has to be obtained [3], [9], [16], [29], [58]. The main problem is associated with the characterization of degradation curve during shearing (from $\tau-\gamma$ for shear modulus $\mathrm{G}$ or $\sigma-\varepsilon$ for deformation modulus E). In the analysis of soil behavior, the term "soil stiffness" is often used while assuming deformations in the elastic range (pseudo-elastic), resulting from static loading, and it is measured as shear stiffness modulus $\mathrm{G}_{0}$, or represented also as initial stiffness modulus $\mathrm{E}_{0}$. These parameters can be estimated based on measured shear wave velocity Vs. The derived parameters $\mathrm{E}_{0}$ and $\mathrm{G}_{0}$ are estimated as:

$$
\begin{gathered}
E_{0}=2 \rho V_{s}^{2}(1+v) \\
G_{0}=\rho V_{s}^{2}
\end{gathered}
$$

where:

$\mathrm{V}_{\mathrm{s}}$ - shear wave velocity, $v$ - Poisson's coefficient, $\rho$ - bulk density .

Shear modulus depends on a number of factors, which were described in the equation presented by Hardin \& Black [after 21]:

$$
G_{0}=f\left(\sigma_{0}^{\prime}, e, S, C, A, F, T, \theta, K\right)
$$


where:

$\sigma_{0}^{\prime}$ - effective horizontal pressure, e - void ratio, $\mathrm{S}$ - saturation ratio, $\mathrm{C}$ - size-mineralogy characteristic, $\mathrm{A}-$ amplitude, $\mathrm{F}$ - frequency, $\mathrm{T}$ - time effects, $\theta$ - soil structure, $\mathrm{T}$ - temperature.

In practice, not all of these parameters are used when estimating the shear stiffness modulus $\mathrm{G}_{0}$ as not all of them have the same impact on the value of shear wave velocity. The most important factors taken into account in most commonly used expressions are void ratio and effective stress, related also to stress history [21]:

$$
\begin{gathered}
G_{0}=A(T) F(e) \sigma_{n}^{\prime} \\
G_{0}=S(T) F(E) \sigma_{n}^{\prime} O C R_{k}
\end{gathered}
$$

where:

$\sigma_{n}^{\prime}-$ effective normal pressure, OCR - over consolidated void ratio, E- deformation modulus,

The equations were proposed by Hardin \& Black and Hardin [21]. To evaluate the small strain shear modulus, the following most common empirical correlations, based on penetration tests results or laboratory results available in literature for various type of soils, are shown below:

a) $\operatorname{Hardin}(1978)$ [21]

$$
G_{0}=6250.3+0.7 e^{2} \cdot O C R_{k} \cdot\left(\sigma_{0}^{\prime} p_{a}\right)^{0.5}
$$

where:

$\mathrm{k}-$ empirical value, $\mathrm{p}_{\mathrm{a}}-$ reference pressure $(98.1 \mathrm{kPa})$

b) Hryciw (1990) [22]

$$
G_{0}=\frac{530}{\left(\sigma_{v}^{\prime} / p_{a}\right)^{0.25}} \frac{\gamma_{D} / \gamma_{w}-1}{2.7-\gamma_{D} / \gamma_{w}} K_{0}^{0.25} \cdot\left(\sigma_{v}^{\prime} \cdot p_{a}\right)^{0,5}
$$

where:

$\mathrm{p}_{\mathrm{a}}$ - reference pressure ( $1 \mathrm{bar}$ ), $\gamma_{\mathrm{D}}$ and $\mathrm{K}_{0}$ are respectively the unit weight and the coefficient of earth pressure at rest, (as inferred from SDMT results according to Marchetti [33]). 
c) Mayne and Rix [37]

$$
G_{0}=\frac{406 \cdot q_{c}^{0.696}}{e^{1.13}}
$$

where:

$\mathrm{G}_{0}, \sigma_{\mathrm{v}}^{\prime}$ and $\mathrm{p}_{\mathrm{a}}$ are expressed in the same units; e- void ratio (this equation is applicable to clay deposits only);

d) Jamiolkowski et al. (1995) [24]

$$
G_{0}=\frac{600 \cdot \sigma_{m}^{\prime 0.5} p_{a}^{0.5}}{e^{1.3}}
$$

where:

$\sigma_{m}^{\prime}=\left(\sigma_{v}^{\prime}+2 \cdot \sigma_{h}^{\prime}\right) / 3 ; p_{a}=1$ bar is a reference pressure; $G_{0}, \sigma_{m}^{\prime}$ and $p_{a}$ are expressed in the same units (this equation is applicable to clay and reconstituted sands)

e) Aoki et al. (1997) [4]

$$
\begin{gathered}
G_{0}=1034 \frac{(2.97-e)^{2}}{1+e} \sigma_{v}^{\prime 0.59} \text { for non-cohesive soils } \\
G_{0}=804 \frac{(2.17-e)^{2}}{1+e} \sigma_{v}^{\prime 0.26} \text { for cohesive soils }
\end{gathered}
$$

The benefits of accounting for non-linearity of this stress-strain relationship has led to the need of measuring soil stiffness over a range of small deformations $\left(10^{-6} \div 10^{-3}\right)$ and utilization of many methods for this purpose [3]. As described by (e.g. Mayne [37], Clayton [9]), several in-situ and laboratory test methods are employed to determine the initial shear modulus $\mathrm{G}_{0}$ (from the shear wave velocity, Vs): Down-Hole (DH) and Cross-Hole (CH) seismic methods, Seismic Dilatometer Test (SDMT) and Seismic Cone Penetration Tests (SCPT), Spectral Analysis of Surface Waves (SASW), Bender Elements Test (BET), Resonance Column (RC). The Dilatometer test (DMT), Pressuremeter Test (PMT), Triaxial Test (TRX), Oedometer test (OET) are also performed to allow assessment of the stiffness of soils at moderate to large strains. Therefore, non-linear behavior of the soil can be determined by many in-situ and laboratory tests. However, to get the shape of this curve it is necessary to make more detailed investigation (in situ and laboratory tests). However such tests are sophisticated and expensive (due to the cost of taking good quality samples, and cost of necessary equipment). It 
is therefore of interest to investigate if in-situ tests can be used to measure G- $\gamma$ stiffness-degradation curves.

This paper focuses on the seismic dilatometer test (SDMT) where the G- $\gamma$ curve is derived from the "initial elastic modulus" $\mathrm{G}_{0}$ based on the shear wave velocity $\mathrm{V}_{\mathrm{S}}$, and a "working strain modulus" $\left(\mathrm{G}_{\mathrm{DMT}}\right)$ corresponding to the Marchetti [32] constrained modulus $\mathrm{M}_{\mathrm{DMT}}$. The seismic dilatometer (SDMT) is the combination of the mechanical flat dilatometer (DMT), introduced by Marchetti, with a seismic module for measuring the shear wave velocity $V_{S}$. From $V_{S}$, the small strain shear modulus $\mathrm{G}_{0}$ may be determined using the theory of elasticity Eq. (1.2). Marchetti et al. [33] first proposed the possible use of the SDMT for deriving in situ soil stiffness variations with strain level (G-curves or similar). A challenging issue, which the scientific community has focused on in the last decade (e.g. [33], [1], [2], [23]), concerns the possibility of assessing the in situ degradation curves of soil stiffness with shear strain (G- $\gamma$ curves), based essentially on the $\mathrm{G}_{0}$ and $\mathrm{G}_{\mathrm{DMT}}$ experimental data alone. This approach has proven applicable to different soil types, as shown by Amoroso et al. [2]. However, limited data are available as to ascertain the reliability of this procedure for soft materials, especially for organic soils.

In short, in this procedure, some curves could be tentatively constructed by fitting "reference typicalshape" laboratory G-curves through two points, both obtained by SDMT: First point - the initial small strain modulus $\mathrm{G}_{0}$, and second point - a working strain modulus $\mathrm{G}_{\mathrm{DMT}}$. To locate the second point on the G-curve it is necessary to know, at least approximately, the shear strain corresponding to GDMT. Researches classified the DMT within the group of methods of measurement of soil deformation characteristics involving an intermediate level of strain (0.01-1\%) - fig. 1. As suggested by Marchetti et al. [33], [34], a working strain shear modulus G $\mathrm{M}_{\mathrm{DMT}}$ provided by the usual DMT interpretation [32]. As a first approximation, by referring to linear elasticity:

$$
G_{D M T}=\frac{1-2 v}{2(1-v)} M_{D M T}
$$

The above tentative method is heavily founded on the assumption that $\mathrm{M}_{\mathrm{DMT}}$ is a reasonable estimate of the working strain modulus [34], [2].

The present paper aims to provide some recommendations for the interpretation of the results from in situ tests commonly used in Polish practice (CPTU, DMT, SDMT). It presents some issues concerning the practical application of field test results obtained mainly using flat dilatometer by Marchetti [32]. The data collected so far allowed to conduct research in the field of determination of 
regional relationships between in situ methods [60], [17], including the presentation of practical applications of results obtained with the dilatometer (DMT/SDMT).

This paper illustrates the use of in situ tests, as indirect CPTU and DMT or direct SDMT, to assess the in situ degradation of stiffness at various test sites, where both SDMT data and "reference" stiffness degradation curves from laboratory tests were available. In this case, an advance triaxial apparatus with bender elements and local (on sample) displacements transducers was used as one of the preferred laboratory methods for obtaining the stiffness parameters of the soil.

\section{Methods AND MATERIAL}

The correlations between sounding results and geotechnical parameters require regional determination or adaptation for local conditions [11], [17], [40], [60]. Additional difficulties are associated with many other factors that have an influence on the soil behaviour and which are still impossible to measure, or their measurements are not reliable enough. The results from new types of static probes with piezocone (CPTU) or flat dilatometer of Marchetti type (DMT) obtained by foreign researchers refer to local soils and very often may not be applicable directly for Polish soil conditions. Some institutions in Poland have conducted intensive research on interpretation methods of CPTU and DMT results for determination of geotechnical parameters ( $\left.\phi^{\prime}, \mathrm{c}_{\mathrm{u} / \mathrm{Su}}, \mathrm{E}_{\mathrm{eod}}\right)$ [5], [6], [15], [17], [26], [27], [30], [40-42], [46-47], [61].

Building Research Institute has extensive experience concerning in situ soil investigations by means of cone penetration test and dilatometer test. The huge number of data points, including different types of soils for different types of construction, has been collected. In the research project [48] the new results were added to the database and statistical analysis was conducted. Wherever it was possible, the modulus obtained from in situ tests was compared to values from back-analysis of settlements measurements. The correlations are based on the results from more than 30 test sites and for different types of soils commonly encountered in Poland. Each test site was considered as a node, consisting of CPTU profile, DMT profile, geological profile, and settlement data [48], [60]. In total, approx. 1700 meters of test profiles were analysed. After extreme values were eliminated, the data was divided into litho-genetic groups from different test sites. When analysing the sounding data with resolution of $20 \mathrm{~cm}$ (DMT), for specific litho-genetic types, data sets of 450 to 1500 data points were obtained. The selected profiles consisted of layers with various properties, lithology and origin, were classified according to the Soil Behaviour Type (SBT) classification rule of Robertson [49], [50]. 


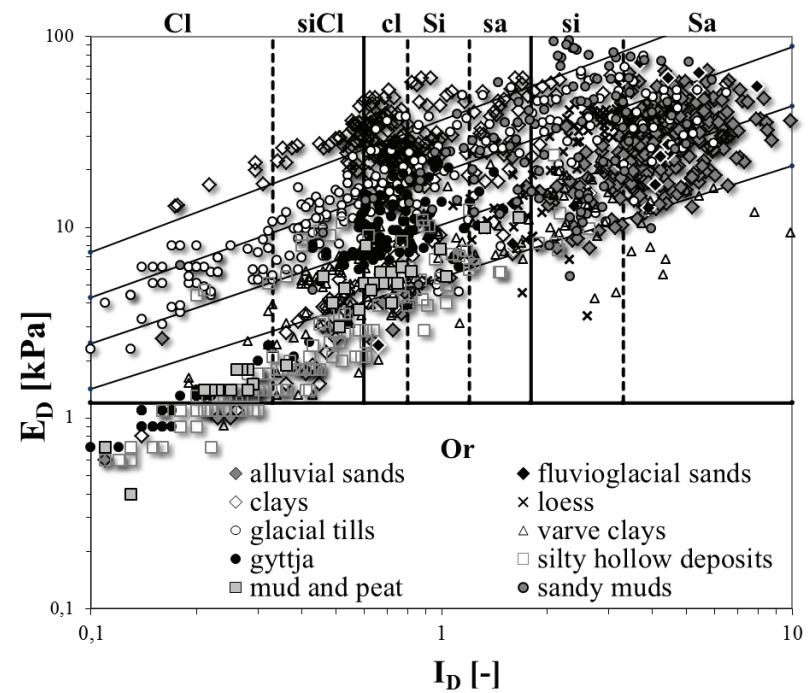

Fig. 2. All results for different test sites for analysed soils plotted on Marchetii's classification nomogram.

These were Miocene-Pliocene clays of Poznan formation (OC), Pleistocene Varve clays $(\sim \mathrm{NC})$, Pleistocene tills of Warta and Odra glacial period (OC), Pleistocene (Eemian interglacial) limnic soil - Gyttja (OC), young Holocene Alluvial soil - soft silty clay (NC) and alluvial NC deposits of River beds - alluvial sands, fluvioglacial OC deposits - fluvioglacial sands, eolian NC deposits - loess, silty hollow deposits NC, OC - silty sands, silty tills and silts, and young Holocene Alluvial - organic NC deposits - mud (alluvium silt) and peat - fig. 2.

\subsection{Calibration of DMT}

The Marchetti flat dilatometer is a device dedicated for determination of deformation parameters of soils. This is supported by the specificity of measurement itself [32]. Expansion of a steel membrane in the soil is a controlled displacement test, i.e. measurement of pressure at desired displacement. This allows for estimating the deformation modulus directly in the soil (in situ) which is the basis for determination of displacements of the designed structure. Worldwide experience [34], [43] [57] indicates that DMT is highly useful in determination of soil deformation moduli. This method is reliable, provided that it is calibrated and validated (by other methods) in local conditions. In this case, the best method is to compare the settlement values measured at given structures or performance of test loads against the settlement values obtained from DMT [43]. 


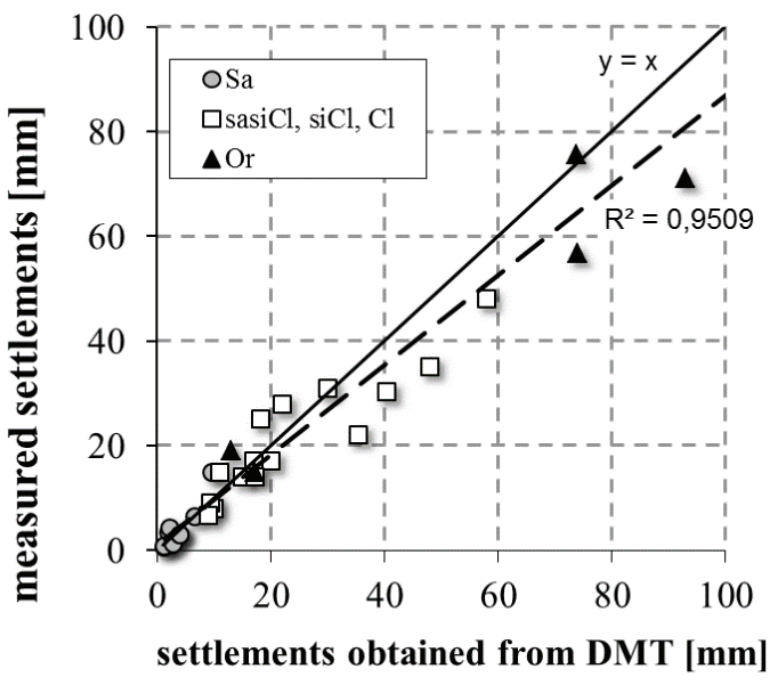

Fig. 3. DMT calibration curve obtained for Polish ground conditions [upgrade from 15]

Acquired experience, in regard to settlement prediction based on DMT, generally confirms the validity of the used equations. Estimated values of moduli, which can be used for settlement prediction, for typical mineral soils, are in line with values obtained from back-analysis of real structures. Fig. 3 shows comparison of settlement values measured at the structures with respect to those obtained by dilatometer data and observations (28 structures) [15]. It should be added that the given set of buildings was limited to structures with shallow foundation. For the purpose of evaluation and forecasting settlement, the dilatometer is a well-calibrated device for typical structures. In the cases of founding on very soft and organic soils, in which the quality of drilling and collected samples is often insufficient, only in situ probing allows for obtaining reliable parameters for design calculations.

\subsection{LOCAL CORRELATION OF CPTU/DMT PROBES}

Currently, cone penetration tests are very common due to the availability of the equipment. The interpretation of obtained measured parameters (cone resistance, sleeve friction, pore pressure) requires the use of correlations to derive geotechnical parameters. When DMT tests cannot be conducted to obtain in situ degradation curve, but data from CPT are available, local correlations have 
to be used. Dilatometric modulus as a more reliable reference value allows for calibration of CPTU results $\left(\mathrm{q}_{\mathrm{c}}\right.$ and $\left.\mathrm{R}_{\mathrm{f}}\right)$ in regard to modulus values. The results obtained at each available test site for various soil type by means of CPTU and DMT soundings were compared. Dilatometer modulus $\left(\mathrm{E}_{\mathrm{D}}\right)$ were converted to confined modulus (M') using Marchetti method [32]. In the first approach to data correlation, the graph of dilatometer modulus $\left(\mathrm{M}_{\mathrm{DMT}}\right)$ versus net cone resistance (comprising vertical stress $\mathrm{q}_{\mathrm{c}}-\sigma_{\mathrm{vo}}$ ) was drawn. The method of linear regression allowed for obtaining the calculation coefficient for each test site. In the second step of analysis, the average value of calculation coefficient for each litho-genetic type of soil was determined. More information about this work is in [17] and the final results are summarized in Table 1. Mean values obtained from correlation for all analyzed types of soils were compared with selected (most popular in literature) experiences of different Authors.

Presented method of interpretation of CPTU method is very simplified (Sanglerat [51], Mayne [36], Młynarek e.t. al. [40]). In literature (e.g. Tanaka et al. [57], Sikora [53], Robertson [49], Wierzbicki [61]), more complex methods for determining the constrained modulus values from CPTU tests are known - with regard to overburden stress $\left(\sigma_{\mathrm{v} 0}\right)$ or stress history (OCR). But this method, based on general formula is still more popular in geotechnical practice.

Table 1 The obtained coefficients on the basis of charts - proposals of empirical cone factors $(\alpha)$ to estimate modulus value $\left(\mathrm{E}_{\mathrm{eod}}\right)$ for Polish grounds conditions, versus literature.

\begin{tabular}{|c|c|c|c|}
\hline \multirow{3}{*}{$\begin{array}{r}\text { Litho-genetic type of } \\
\text { soil: }\end{array}$} & \multicolumn{3}{|c|}{ empirical cone factor $(\alpha)$} \\
\hline & \multirow{2}{*}{$\begin{array}{c}\text { mean value } \\
\text { obtained from } \\
\text { correlation }\end{array}$} & \multicolumn{2}{|c|}{ from literature (Sanglerat [51] ${ }^{1}$; Sikora [53 $]^{2} ;$ Młynarek [40]) } \\
\hline & & proposed value & Author(s) \\
\hline $\begin{array}{r}\text { alluvial sands } \\
\text { NC }\left(q_{\mathrm{c}}=3 \div 10\right) \\
\text { OC }\left(\mathrm{q}_{\mathrm{c}}>10\right)\end{array}$ & $\begin{array}{l}3,7 \\
9,8\end{array}$ & $\begin{array}{c}4 \text { or } 2(+20 \mathrm{MPa}) \\
3\end{array}$ & $\begin{array}{l}\text { Lunne, Christophersen }(1983)^{2} \\
\text { Vermeer }(2000)^{2}\end{array}$ \\
\hline fluvioglacial sands OC & 20,2 & $\sim 5,\left(\mathrm{q}_{\mathrm{c}}<50 \mathrm{MPa}\right)$ & $\begin{array}{l}\text { Lunne, Christophersen }(1983)^{2} \text { Vermeer } \\
\qquad(2000)^{2}\end{array}$ \\
\hline $\begin{array}{r}\text { tertiary clays: } \\
\text { clays from Cracow } \\
\text { OC } \\
\text { clays from Warsaw } \\
\text { OC }\end{array}$ & $\begin{array}{l}19,4 \\
12,1\end{array}$ & $\begin{array}{c}4 \\
5 \div 8 \\
1 \div 2,5 \\
\left(\mathrm{q}_{\mathrm{c}}<2 \mathrm{MPa}\right) \\
7\end{array}$ & 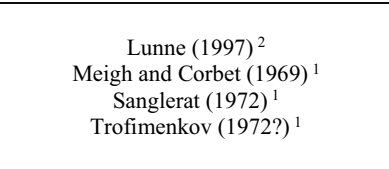 \\
\hline glacial tills OC & 11,1 & $\begin{array}{c}5 \div 10 \\
8,25\end{array}$ & $\begin{array}{c}\text { Senneset }(1989)^{2} \\
\text { Kulhawy, Mayne }(1990)^{2}\end{array}$ \\
\hline loess deposits & 6,9 & \multirow[b]{2}{*}{$3 \div 6\left(\mathrm{q}_{\mathrm{c}}<2 \mathrm{MPa}\right)$} & \multirow[b]{2}{*}{ Sanglerat $(1972)^{1}$} \\
\hline $\begin{array}{r}\text { hollow deposits: } \\
\text { silty sands NC } \\
\text { slity clays and silts } \\
\text { OC }\end{array}$ & $\begin{array}{l}3,5 \\
7,0\end{array}$ & & \\
\hline $\begin{array}{r}\text { organic soils: gyttja } \\
(\mathrm{OC}) \\
\mathrm{mud} / \text { peat NC }\end{array}$ & $\begin{array}{l}6,9 \\
4,6\end{array}$ & $\begin{array}{c}\text { all organic soils } 2 \div 8 \\
\left(\mathrm{q}_{\mathrm{c}}<1,2 \mathrm{MPa}\right) \\
10,2 \\
8,5\end{array}$ & $\begin{array}{c}\text { Sanglerat (1972) }{ }^{1} \\
\text { Młynarek et. all (2013) }\end{array}$ \\
\hline
\end{tabular}




\subsection{SHEAR MODULUS FROM SDMT}

Currently, apart from the standard DMT test, the tests involving geophysical measurements with a dilatometer with a seismic sensor (SDMT) have been often performed. More information on the procedure itself and factors affecting the reliability of obtained results can be found in [33] and [18], [19]. These tests allow for determination of the soil rigidity profile as a function of shear modulus $\left(\mathrm{G}_{0}\right)$ by measuring the propagation velocity of a transverse wave $\left(\mathrm{V}_{\mathrm{s}}\right)$. Due to sufficient experiences of testing with the use of DMT and SDMT, correlations were established, which may be useful when direct seismic measurements are not available. Below, three basic relationships established by Marchetti et al. [33], [34], are presented:

$$
\begin{gathered}
G_{0}=M_{D M T} \cdot 26.177 \cdot K_{D}^{-1.0066} \text { for clayed soils } \\
G_{0}=M_{D M T} \cdot 15.686 \cdot K_{D}^{-0.921} \text { for silty soils } \\
G_{0}=M_{D M T} \cdot 4.5613 \cdot K_{D}^{-0.7967} \text { for sandy soils }
\end{gathered}
$$

where:

$\mathrm{M}_{\mathrm{DMT}}-$ dilatometer modulus [MPa], $\mathrm{K}_{\mathrm{D}}$ - coefficient of horizontal stress [-]

Equations by Marchetti et al. [34] were based on a large spectrum of test results from 34 test locations, where 2000 parameter values were obtained. The examples of local correlations (especially for organic soils), based on the formula presented by Marchetti, are presented below:

f) Rabarijoely (2008) [46]

$$
G_{0}=2.98 \cdot M_{D M T} \cdot K_{D}^{-1.2} \text { for organic soils }
$$

g) Młynarek et al. (2013) [40]

$$
\begin{gathered}
G_{0}=49.97 \cdot M_{C P T U} \cdot K_{D}^{-1.0} \text { for sands } \\
G_{0}=12.35 \cdot M_{C P T U} \cdot O C R^{0,13} \text { for organic soils }
\end{gathered}
$$

In Poland, some other attempts of regional correlations have already been carried out for organic soil and soft clays by Młynarek et al. [42], Lechowicz et al. [26]. These Authors, for example, define a specific correlation between the Dilatometer Modulus Ed and the Young modulus at $0.1 \%$ level of strain. Similarly, the results from SDMT were used to obtain correlation relationships for the tested soils at the described test sites. 


\subsection{REFERENCE LABORATORY TEST}

For laboratory investigation of elastic deformation characteristics of soils in the range of small strains, with the use of shear wave velocity measurements, the Bender Element Test (BET) was used. This test is often conducted in the triaxial apparatus cell, with the use of piezoelements. Generated and received S- and P-waves allow for estimating the Poisson's coefficient and the initial deformation modulus $\mathrm{E}_{0}$ of the tested soil. More details about this equipment and technical information were presented in [7], [12], [62].

In this paper, only the results for natural cohesive soils are presented, namely, glacial tills from northern and central Poland and Neogene clays (tab. 2). A total of about 130 samples were taken from the investigation sites for laboratory tests. The tests were carried out using triaxial testing devices. The tests were conducted on undisturbed soil samples, either $70 \mathrm{~mm}$ in diameter and the height of $140 \mathrm{~mm}$, or the diameter of $38 \mathrm{~mm}$ and the height of $75 \mathrm{~mm}$. The samples were saturated with an automatic pressure control algorithm, until B coefficient reached a value greater than 0.95 . After the saturation phase, the isotropic consolidation stage was carried out, followed by the S-wave transition measurements with bender element tests (BET) together with the use of local displacement transducers. In the case of $38 \mathrm{~mm}$ diameter samples, both the shear wave and the compressional wave (P-wave) velocities were measured.

Due to the height of the samples, expected range of wave velocities, as well as the need to minimize „near field” effects, the procedure presented by Camacho-Tauta et al. [8] as well as Godlewski and Szczepański [18] were used. Generated vibrations had a frequency of less than $4 \mathrm{kHz}$. Thanks to that, the ratio of sample height to wave length $L / \lambda$ was higher than 3 [18], which allowed to eliminate factors that might have affected the results. For the analysis of the signal, visual interpretation was used, using a method described as ,major first peak” by Lee and Santamarina [28]. Additionally, lowpass filter was used with the frequency of $10 \mathrm{kHz}$, which helped with the removal of the noise. More details about the procedure and some aspects of measurement were described by Witowski [62]. The basic statistical information concerning selected parameters of the tested soils are presented in table 1. More detailed characteristic and statistical distributions for analyzed soils were presented by Bogusz and Witowski [7]. The tests were conducted at the confining pressures between $15 \mathrm{kPa}$ to $2000 \mathrm{kPa}$, with most data is range from 100 up to $500 \mathrm{kPa}$. 
Table 2. Summary of basic properties for analyzed soils a) clays; b) glacial tills [7].

\begin{tabular}{|c|c|c|c|c|c|c|c|c|c|c|c|c|}
\hline \multirow{3}{*}{$\begin{array}{l}\text { Statistical } \\
\text { parameters }\end{array}$} & \multicolumn{2}{|c|}{ Moisture content } & \multicolumn{2}{|c|}{$\begin{array}{l}\text { Initial void } \\
\text { ratio }\end{array}$} & \multicolumn{2}{|c|}{$\begin{array}{l}\text { Plasticity } \\
\text { index }\end{array}$} & \multicolumn{2}{|c|}{$\begin{array}{l}\text { Liquidity } \\
\text { index }\end{array}$} & \multicolumn{2}{|c|}{$\begin{array}{l}\text { Volume } \\
\text { density }\end{array}$} & \multicolumn{2}{|c|}{$\begin{array}{l}\text { Initial shear } \\
\text { modulus }\end{array}$} \\
\hline & \multicolumn{2}{|c|}{$\mathrm{w}_{\mathrm{c}}[\%]$} & \multicolumn{2}{|c|}{$\mathrm{e}_{0}[-]$} & \multicolumn{2}{|c|}{$\mathrm{I}_{\mathrm{P}}[\%]$} & \multicolumn{2}{|c|}{$\mathrm{I}_{\mathrm{L}}[\%]$} & \multicolumn{2}{|c|}{$\rho\left[\mathrm{Mg} / \mathrm{m}^{3}\right]$} & \multicolumn{2}{|c|}{$\mathrm{G}_{0}[\mathrm{MPa}]$} \\
\hline & a) & b) & a) & b) & a) & b) & a) & b) & a) & b) & a) & b) \\
\hline Min & 16,80 & 8,57 & 0,44 & 0,23 & $\begin{array}{c}34,7 \\
6\end{array}$ & $\begin{array}{c}10,2 \\
2\end{array}$ & $-0,12$ & $-0,07$ & 1,93 & 2,01 & 44,54 & 45,90 \\
\hline Max & 30,82 & 20,08 & 0,82 & 0,54 & $\begin{array}{c}140 \\
4\end{array}$ & $\begin{array}{c}25,6 \\
9\end{array}$ & $-0,01$ & 0,41 & 2,15 & 2,38 & 217,7 & 592,5 \\
\hline Arithmetic average & 20,71 & 13,21 & 0,57 & 0,37 & $\begin{array}{c}55,3 \\
9\end{array}$ & $\begin{array}{c}15,0 \\
8\end{array}$ & $-0,06$ & 0,19 & 2,06 & 2,20 & 119,1 & 185,1 \\
\hline Standard deviation & 4,37 & 2,69 & 0,10 & 0,06 & $\begin{array}{c}30,7 \\
4\end{array}$ & 3,69 & 0,04 & 0,12 & 0,06 & 0,07 & 47,62 & 114,9 \\
\hline $\mathrm{CoV}[\%]$ & 21,1 & 20,4 & 17,9 & 16,2 & 55,5 & 24,5 & $-58,7$ & 63,2 & 3,08 & 3,18 & 40,0 & 62,1 \\
\hline
\end{tabular}

\section{RESULTS}

\subsection{RESULTS FROM SDMT}

The presented data offer the first correlation of this type for soils in Poland. The SDMT method was validated by surface geophysical methods (CSWS and SASW) [18, [19]. New correlation relationships have been examined for typical soils present in Poland, for which the possibility of estimation of initial shear modulus $\mathrm{G}_{0}$ was investigated on the basis of the standard results from DMT tests. The amount of data is already statistically significant in some cases (e.g. sands); however, the coherence of the results is still below the level for the relation to be meaningful. The observed scatter undoubtedly originates from the variability and diversity of the studied material. These results correspond well with the distribution of $\mathrm{G}_{0} / \mathrm{M}_{\mathrm{DMT}}$ versus $\mathrm{K}_{\mathrm{D}}$ (fig.4). The graph presents the results from chosen tests sites and soil types, and the results confirm the facts given in Marchetti et al., [34]. Obtained correlations present various levels of reliability. Nonetheless, presented equations for glacial tills, clays, and sand, can be used in practice for prediction of the stiffness degradation curve. 

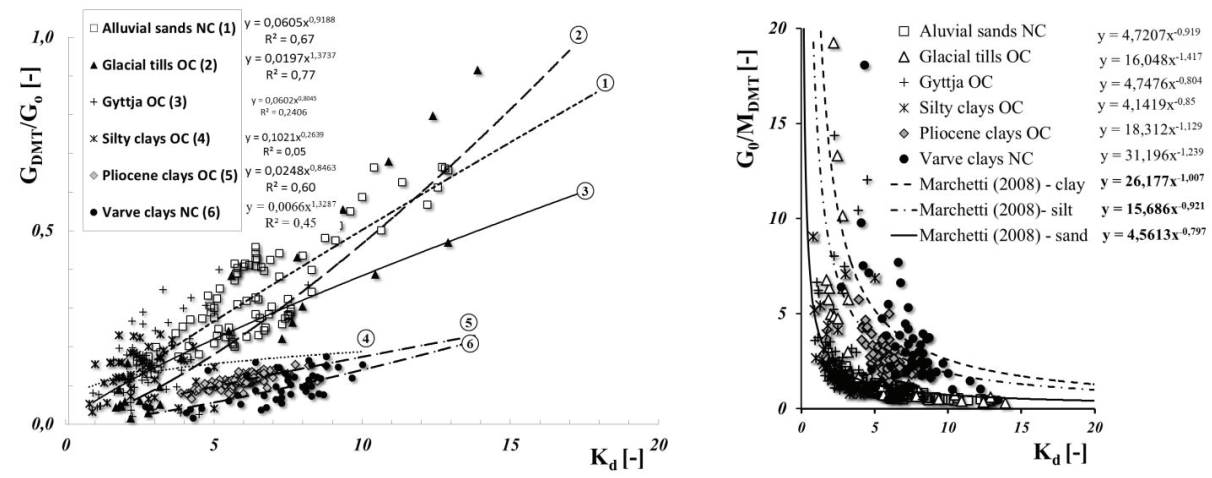

Fig. 4. Graph of the $\mathrm{G}_{\mathrm{DMT}} / \mathrm{G}_{0}$ (left) and $\mathrm{G}_{0} / \mathrm{M}_{\mathrm{DMT}}$ indicator (right) vs $\mathrm{K}_{\mathrm{D}}$ for chosen types of soils [18] with modifications.

\subsection{RESULTS FROM LABORATORY TESTS}

The presentation and the analysis of the results contained in the database of laboratory test results has been limited mainly to two soil types which were investigated, namely: "Pliocene" clays and glacial tills. Glaciation processes have been responsible for significant overconsolidation of those soils, observed now in OCR with typical values of 8-12 up to 50 (for Warsaw clays) [ ]. The obtained results from all tests (laboratory and in situ) were summarized in graphs (Fig. 5).

Those graphs show that results from laboratory tests for OC clays and glacial tills are separated due to different shape of a normalized degradation curve (in function $\mathrm{G} / \mathrm{G}_{0}-\gamma$ ). Results obtained for glacial tills exhibit larger scatter of degradation range than clays. This situation is typical for this type of soil because of its natural variability.

In order to construct the G- $\gamma$ degradation curve, it is necessary to locate the working strain modulus $\mathrm{G}_{\text {DMT. }}$ In other words, it is necessary to know, at least approximately, the shear strain corresponding to GDMT. Indications by Mayne [36] locate the DMT modulus (М level of strain $(\gamma \approx 0.05-0.1 \%)$. Similarly Ishihara (after [2]) classified the DMT within the group of methods of measurement of soil deformation characteristics involving also an intermediate strain level (0.01-1\%). More recent studies [2], [23] clearly showed that the working strain modulus depends on the soil texture: typical working strain ranges of $\mathrm{G}_{\mathrm{DMT}}$ can be approximately assumed as $0.01-$ $0.45 \%$ in sand, $0.1-2 \%$ in silt and clay, while higher than $2 \%$ in soft clay. 

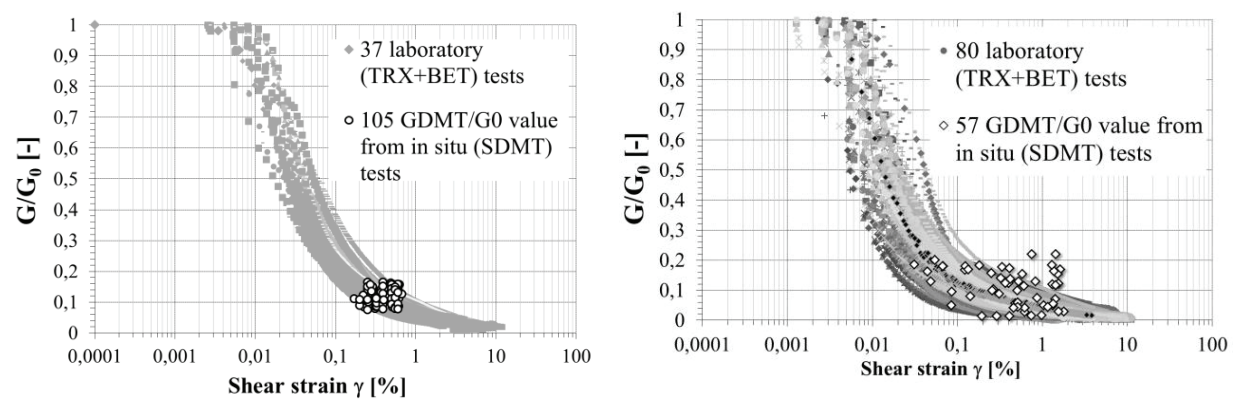

Fig. 5. Shape of the normalized $\mathrm{G} / \mathrm{G}_{0}-\gamma$ degradation curve's range and values of $\mathrm{G}_{\mathrm{DMT} / \mathrm{G}_{0}-\gamma_{\mathrm{DMT}}}$ based on the SDMT for OC clays (on left) and OC glacial tills (on right).

Next for estimating the shear strain the SDMT data obtained at the same depth were use. Based on M DMT and using constitutional Eq. (1.12), a working strain modulus $\mathrm{G}_{\mathrm{DMT}}$ was derived. For both types of soils, the estimated values of Poisson's coefficient from laboratory tests, were chosen as an average (0.3). Also for obtaining a normalized value, a small strain value $\mathrm{G}_{0}$ was derived from $\mathrm{V}_{\mathrm{s}}$. After that, the horizontal ordinate line was superimposed to the same depth on proposed reference stiffness degradation curve. The intersection of the $\mathrm{G}_{\mathrm{DMT}} / \mathrm{G}_{0}$ value provides a shear strain value referred as

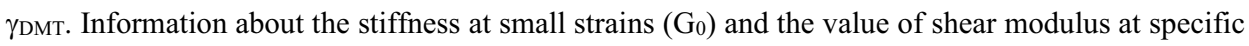
shear strain provides two points through which an interpolation of the data from the laboratory can be made in order to get the complete in-situ degradation curve G- $\gamma$. The values of the normalized working shear strain modulus ratio $\mathrm{G}_{\mathrm{DMT}} / \mathrm{G}_{0}$ range from 0.08 to 0.16 in clays and 0.01 to 0,2 in glacial tills, while the range of values of the shear strain $\gamma_{\mathrm{DMT}}$ are $0.2 \%$ to $0.6 \%$ in clays, $0.04 \%$ to $1.8 \%$ in silty, sandy stiff clays (tills). Those results show that in OC soils, faster increase in stiffness with stress level and faster reduction in stiffness with strain level is visible than for typical NC, soft soils. These observations are in agreement with preliminary literature indications [31], [34], [44], [23], [52], [58].

\section{EVALUATION OF IN SITU STIFFNESS DEGRADATION CURVE}

The present paper aims to provide some recommendations for the interpretation of the results from in situ tests used in Polish practice (SDMT) for estimating the G- $\gamma$ degradation curves for various type of soils. According to this procedure, if one were to define the in situ degradation curve, a reference strain level has therefore to be assigned. An alternative approach proposed here is to assign the shear 
strain level and estimate shear strain stiffness, at that level, starting from SDMT results. The nonlinear stress-strain behavior of soils at small to medium strains is mostly represented by some form of hyperbolic stress-strain relationship [13], [20], [56], [59]. After Darendeli [10], the best-fit functional relationship for the secant shear modulus degradation data as a modified hyperbolic equation takes the form:

$$
\frac{G}{G_{0}}=\frac{1}{1+\left(\frac{\gamma-\gamma_{e}}{\gamma_{r}}\right)^{a}}
$$

where:

$\mathrm{G}$ - the secant shear modulus at any strain $(\gamma), \gamma_{\mathrm{r}}-$ reference strain value at which $\mathrm{G} / \mathrm{G}_{0}=0,50, \gamma_{\mathrm{e}}-$ elastic threshold strain beyond which the shear modulus falls below maximum, a - curvature parameter
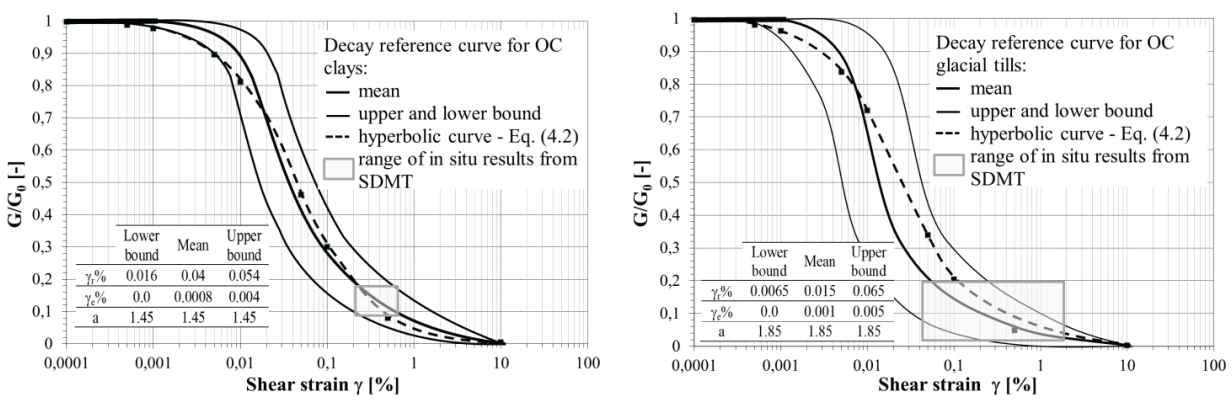

Fig. 6. Reference stiffness degradation curve for OC soils (for clays on left and glacial tills on right) and range of in situ results from SDMT.

Correction of this equation (after Bolton [56]) including $\gamma_{\mathrm{e}}$ as an additional curve-fitting parameter, is very useful because it helps to cover cementation and interlocking effects at small strains. For obtained datasets (clays and tills), stiffness degradation curves were established (fig. 6). Based on all results, average curve with upper- and lower-boundary was established. Parameters of the obtained curves, based on the equation (4.1) are presented.

Those models, with the implemented procedure (fig. 7) and established relationships, allow for evaluation of soil behaviour, based on in situ tests, at full range of deformations. At fig. 6, additional validation of those models was presented. This shear strain stiffness could be estimated by defining 
the relation between $\mathrm{G}_{\mathrm{DMT}}$ and the Dilatometer Modulus. The one of SDMT data determined at the investigated test sites was used to assist the construction of a hyperbolic stress-strain equation [2]:

$$
\frac{G}{G_{0}}=\frac{1}{1+\left(\frac{G_{0}}{G_{D M T}}-1\right) \frac{\gamma}{\gamma_{D M T}}}
$$

The ratio $\mathrm{G}_{\mathrm{DMT}} / \mathrm{G}_{0}$ obtained from SDMT and the estimated shear strain $\gamma_{\mathrm{DMT}}$ were used to plot the corresponding hyperbolic curve at one of test sites (typical for analyzed clays and glacial tills). The curves obtained from SDMT, using Eq. (4.2), presented on graph (black dash lines in Fig. 6) provide a reasonable fit to the proposed models (reference stiffness degradation curves). Based on the conducted analysis, as a summary, a proposal of a procedure is presented for evaluating stiffness characteristic based on in situ tests (fig. 7).

The diagram presents subsequent steps of the proposed method, depending on the availability of the test methods and their results. In the step I, when evaluating the stiffness degradation model, the use of DMT and SDMT with additional reference curves is preferred. Alternatively, the use of CPT with validated regional correlations (step II) can be used to obtain necessary stiffness parameters $\left(\mathrm{G}_{\mathrm{DMT}}\right)$. Next stage (step VI) regard estimation of $\mathrm{G}_{0}$ (based on seismic tests with $\mathrm{V}_{\mathrm{s}}$ measurements). The points of the reference curve can be chosen using these data. Characterizing the stiffness of each ground requires the use of databases and establishing degradation models (step VI). With lack of such data, direct laboratory measurements can be used (step V). However, due to variability of most soils and usually very limited number of laboratory tests, this approach may not be representative. In such case, reference to data available in the literature is recommended. Last stage (step VII) is related to fitting of the typical shape (reference typical-shape from laboratory G- $\gamma$ curves) using established two parameters $\left(\mathrm{G}_{0}\right.$ and $\left.\mathrm{G}_{\mathrm{DMT}} / \mathrm{G}_{0}\right)$. Locating the second point on the $\mathrm{G}-\gamma$ curve is the main issue. 


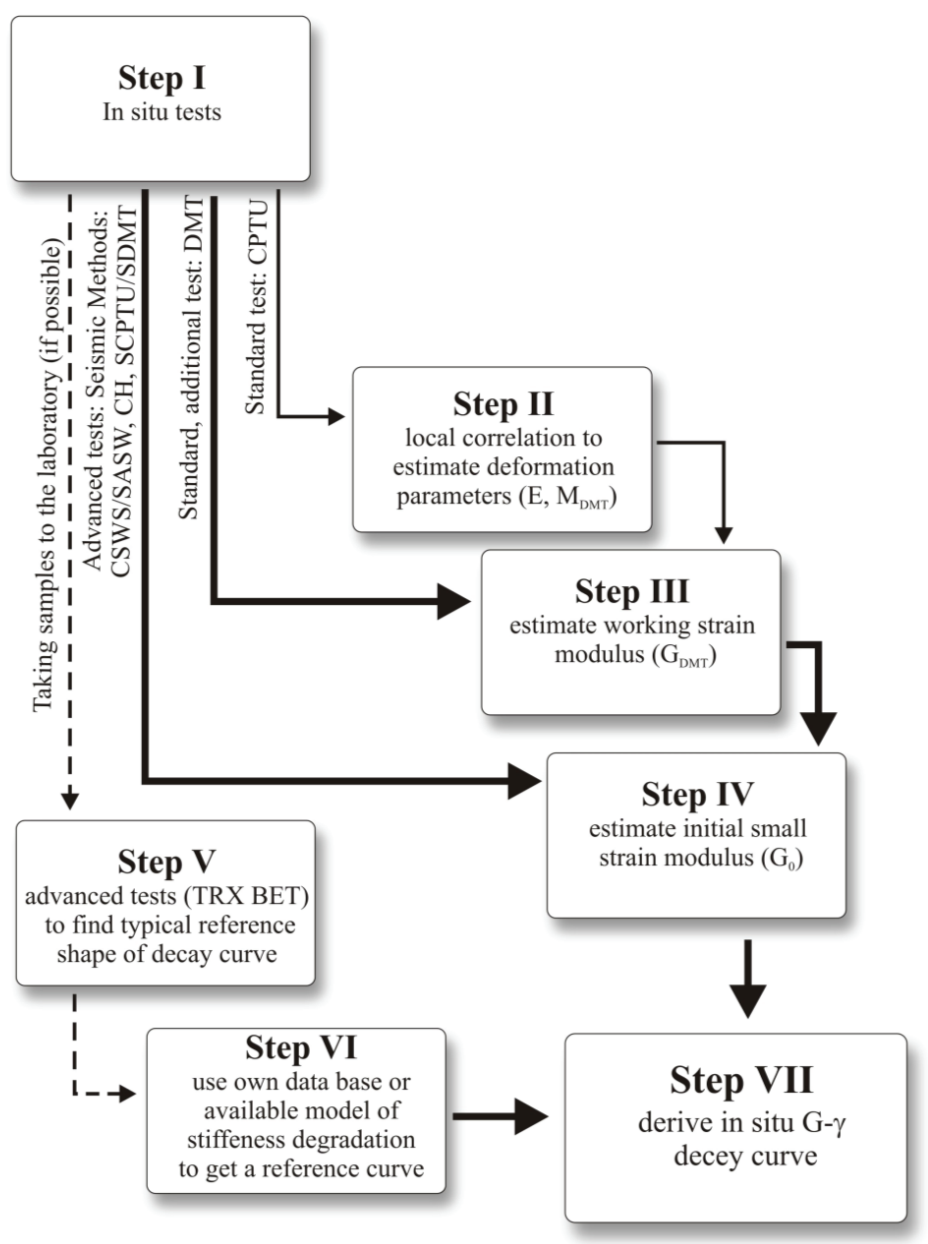

Fig. 7. Proposition of the procedure of evaluation of stiffness degradation curves from in situ tests.

It is necessary to know (at least approximately) the shear strain $\gamma_{\mathrm{DMT}}$ corresponding to working strain modulus GDMT. Typical ranges of $\gamma_{\text {DMT }}$ in different soil types could been inferred from the "intersection" of the SDMT data points with same-depth reference stiffness degradation curves back-analyzed from the observed field behaviour under full-scale loading, or obtained by cyclic/dynamic laboratory tests, or reconstructed by the combined use of different in situ/laboratory techniques - at various test sites. 


\section{CONCLUSION}

The development of interpretation methods of soundings is based mainly on statistical correlations which demand huge sets of measurements. The correlations between sounding results and geotechnical parameters require good regional determination or adaptation for local conditions. The results presented in this paper support the possible use of the CPTU, DMT and SDMT to assess the degradation of in situ stiffness with increase of strain level. This potential stems from the ability of the SDMT to provide routinely, at each test depth, both a small strain stiffness $\left(\mathrm{G}_{0}\right.$ from $\left.\mathrm{V}_{\mathrm{S}}\right)$ and a working strain stiffness $\mathrm{G}_{\mathrm{DMT}}$ (derived via standard DMT correlations).

Presented results have high statistical value - approx. 3000 data points were used for the analysis of CPTU/DMT correlation, about 300 results from SDMT profiles, and about 130 laboratory tests (curves) to estimate reference shapes of degradation curves. Of course, it is recognized that given values require consideration of additional factors, accounting for uncertainty in correlation parameters. Especially, in the case of overconsolidated soils, the impact of stress history plays an important role on evaluation of stiffness characteristic [27], [29]. Some aspects and methodology associated with evaluation of overconsolidated soils (in Polish conditions) can be found in works of Wierzbicki [61].

The correlations presented in the article are based of solutions from the literature, therefore widely recognized and already applied in practice, but with additional considerations for local experience so they may be used in the Polish practice with less uncertainty.

\section{REFERENCES}

1. S. Amoroso, P. Monaco, D. Marchetti, "Use of the Seismic Dilatometer (SDMT) to estimate in situ G-y decay curves in various soil types", Proc. of the ISC'4, Porto de Galinhas, Brasil. CRS Press Taylor\&Francis Group, Vol. 1, pp. 489-497, 2012.

2. S. Amoroso, P. Monaco, B. M. Lehane, D. Marchetti, "Examination of the Potential of the Seismic Dilatometer to Estimate In Situ Stiffness Decay Curves in Various Soil Types". Soils and Rocks, 37(3), 177-194, 2014.

3. J. H. Atkinson, "Non-linear soil stiffness in routine design". Géotechnique 50 (5): 487-508, 2000.

4. M. Aoki, M. Kakurai, O. Ishii, K. Ishihara, "Field measurements and predictive estimates of ground heave and settlement of bearing stratum supporting the spread fundation of a skyscraper", AJJ.J. Technology Des., No.5, 80-84, 1997.

5. L. Bałachowski, P. Kozak, N. Kurek, „Intercorrelation between CPTU-DMT test for sands on the Baltic coast", Proc. of 11th Baltic Sea Geotechnical Conference, Gdańsk. Geotechnics in Marintime Engineering. Z. Młynarek, Z. Sikora \& E. Dembicki (ed.). Vol. 1. Printing-Office MISIURO, Gdańsk: 359-366, 2008.

6. M. Barański, T. Godlewski, T. Szczepański, „Determination of soil stiffness parameters on chosen test sites, using in situ seismic methods", Proc. 4th Int. workshop: Soil parameters from in situ and laboratory tests. Poznań, s. 149-157, 2010.

7. W. Bogusz, M. Witowski, "Variability of overconsolidated soils from Poland in geotechnical practice", Proc. XVI Danube European Conf. on Geotech. Eng., Skopje, Macedonia, 585-590, 2018. 
8. J. F. Camacho-Tauta, J. D. J. Alvarez, O. J. Reyes-Ortiz, "A procedure to calibrate and perform the bender element test", Dyna, 79: 10-18, 2012.

9. C. R. I. Clayton, "Stiffness at small strain: research and practice", Geotechnique 61, (1), 2011.

10. B. M. Darendeli, "Development of a new family of normalized modulus reduction and material damping curves. $\mathrm{PhD}$ dissertation, University of Texas at Austin, TX, USA, 2001.

11. M. Dysli, W. Steiner, "Correlations in soil mechanics”. PPUR Presses Polytechniques, 92, 2011.

12. R. Dyvik, C. Madhus, "Lab measurements of Gmax using bender elements", Advance in the art of testing soils under cyclic conditions (ed. V. Koshla), New York, ASCE, 186 - 196, 1985.

13. M. Fahey, J. P. Carter, "A finite element study of the pressuremeter test in sand using a nonlinear elastic plastic model. Can. Geotech. J. 30, No. 2, 348-362, 1993.

14. S. Foti, C. G. Lai, G. J. Rix, C. Strobbia, "Surface Wave Methods for Near-Surface Site Characterization". CRC Press Taylor \& Francis Group, 46 - 48, 6000 Broken Sound Parkway NW, 2015.

15. T. Godlewski, "Practical use of the dilatometer tests - some case studies from Poland", Proc. of The 3rd Int. Conf. on the Flat Dilatometer DMT'15, Rome. Marchetti, Monaco \& Viana da Fonseca (edit.): 99-106, 2015.

16. T. Godlewski, G. Kacprzak, M. Witowski, „Practical evaluation of geotechnical parameters of soils for the design of diaphragm walls embedded in Warsaw's Pliocene clays", Civil and Environmental Engineering, Vol. 4, No.1, 13-19, 2013. In polish.

17. T. Godlewski, M. Wszędyrówny-Nast, „Correlations of regional geotechnical parameters on the basis of CPTU and DMT tests". Proc. of 13th Baltic Sea Geotechnical Conference, Vilnius Gediminas Technical University Press, pp. 22-27, 2016.

18. T. Godlewski, T. Szczepański, "Measurement of soil shear wave velocity using in situ and laboratory seismic methods - some methodological aspects", Geological Quarterly, Vol. 59, No 2, pp. 358-366, 2015.

19. T. Godlewski, T. Szczepański, "Methods for determining soil stiffness in geotechnical investigations, guidance, Poradnik ITB, Warszawa, 2015. In polish.

20. B. O. Hardin, V. P. Drnevich, "Shear modulus and damping in soils: design equations and curves", J. Geotech. Eng. 98, No. 7, 667-692, 1972.

21. B.O. Hardin, "The nature of stress-strain behaviour of soils, State-of-the-art report", Proc. Spec. Conf. on Earthquake Engineering and Soil Dynamics, pp. 3-90, 1978.

22. R. D. Hryciw, "Small Strain Shear Modulus of Soil by Dilatometer", JGED, ASCE, Vol. 116, No. 11, pp. 1700$1715,1990$.

23. K. Ivandic, M. Spiranec, B. Kavur, S. Strelec, "Determining G- $\gamma$ Degradation Curve in Cohesive Soils by Dilatometer and in situ Seismic Tests", World Academy of Science, Eng. and Techn. Inter. Journal of Geotech. and Geolog. Eng. 12(2): 144-151, 2018.

24. M. Jamiolkowski, D. C. F. Lo Presti, O. Pallara, "Role of In-Situ Testing in Geotechnical Earthquake Engineering", Proc. of $3^{\text {rd }}$ Int. Conf. on Recent Advances in Geotechnical Earthquake Engineering and Soil Dynamic, State of the Art 7, St. Louis, Missouri, Vol. II, pp. 1523-1546, 1995.

25. R. J. Jardine, D. M. Potts, A. Fourie, J. B. Burland, "Studies of the Influence of Non-Linear Stress-Strain Characteristics in Soil-Structure Interaction", Geotechnique, Vol. 36, No.3, 377-396, 1986.

26. Z. Lechowicz, M. Bajda, S. Rabarijoely, G. Wrzesinski, "Use of SDMT for the evaluation of the geotechnical parameters of organic soils." Proc. 5th Int. Workshop on CPTU and DMT in soft clays and organic soils. Poznan, Poland, 107-118, 2014.

27. Z. Lechowicz, S. Rabarijoely, T. Kutia, "Determination of undrained shear strength and constrained modulus from DMT for stiff overconsolidated clays", Annals of Warsaw University of Life Sciences - SGGW, Land Reclam., 49 (2), pp. 107-116, 2017.

28. J. S. Lee, J. C. Santamarina, "Bender elements: performance and signal interpretation", Journal of Geotechnical and Geoenvironmental Engineering, 131: 1063-1070, 2005.

29. M. L. Lipiński, „Criteria of estimation of geotechnical parameters”, Polimax s.c., Warszawa, 2013. In polish.

30. M. L. Lipiński, W. Tymiński, „Evaluation of initial stiffness of natural overconsolidated soils, Proc. of 15 th Eur. Conf. on Soil Mech. Geot. Eng. IOS Press, 209-214, 2011.

31. K. R. Massarsch, "Deformation properties of fine-grained soils from seismic tests". Proc. Int. Conf. on Site Characterization, ISC'2, Porto, Portugal, pp. 133-146, 2004.

32. S. Marchetti, "In Situ Tests by Flat Dilatometer". Journal of the Geotechn. Engineering Division, ASCE, Vol. 106, No. GT3, 299-321, 1980.

33. S. Marchetti, P. Monaco, G. Totani, D. Marchetti, "In Situ tests by seismic dilatometer (SDMT)", Laier, J.E.; Crapps D.K. \& Hussein M.H. (eds) From Research to Practice in Geotechnical Engineering. Geotechnical Special Publication, ASCE, v. 180, p. 292-311, 2008.

34. D. Marchetti, S. Marchetti, P. Monaco, "Interrelationship between small strain modulus Go and operative modulus", Prepared for IS-Tokyo - Earthquake Geotechnical Engineering Conference, from Case History to Practice IS-Tokyo 2009, T. Kokusho, Y. Tsukamoto and M. Yoshimine (eds), Taylor \& Francis Group, London, Tsukuba, JapanVolume: 1315-1323, 2009. 
35. M. C. Matthews, C. R. I Clayton, Y. Own, "The use of geophysical techniques to determine geotechnical stiffness parameters", Proc. Instn. Civ. Eng. Geotech. Eng, 143, 31-42, 2000.

36. P. W. Mayne, "Stress-strain-strength-flow parameters from enhanced In-situ tests", Proc. of Int. Conf. on In Situ Measurement of Soil Properties \& Case Histories (In Situ 2001), Bali: 27-48, 2001.

37. P.W. Mayne, G. J. Rix, "Gmax -qc Relationships for Clays”, Geotechnical Testing Journal, Vol. 16, No. 1, pp. 54-60, 1993.

38. M. Mitew-Czajewska, A. Siemińska-Lewandowska, "The effect of deep excavation on surrounding ground and nearby structures", Proceedings of the 6th International Symposium (IS-Shanghai 2008), Shanghai, China, Geotechnical Aspects of Underground Construction in Soft Ground / Ng C.W.W., Huang H.W., Liu G.B. (eds), CRC Press/Balkema: 201-206. 2009.

39. M. Mitew-Czajewska, "Parametric study of deep excavation in clays". Bulletin of the Polish Academy of Sciences, Technical Sciences 66 (5): 747-754, 2018.

40. Z. Młynarek, S. Gogolik, G. Sanglerat, "Interrelationship between deformation moduli from CPTU and SDMT tests for overconsolidated soils". Proc. of the 18th Int. Conf. on Soil Mechanics and Geotech. Eng., Paris: 583$586,2013$.

41. Z. Młynarek, J. Wierzbicki, A. Smaga, ,Initial shear modulus of soils of different origin from SCPTU \& SDMT, 6th Int. Workshop In situ \& Lab. Char. of OC subsoil, Poznań, Poland, 57-68, 2017.

42. Z. Młynarek, K. Stefaniak, J. Wierzbicki, „Evaluation of deformation parameters of organic subsoil by means of CPTU, DMT, SDMT”, Architecture Civil Engineering Environment, Vol. 6, No 4, 51-58, 2013.

43. P. Monaco, G. Totani, M. Calabrese, "DMT - predicted vs observed settlements: a review of the available experience", Proc. from the Second Int. Flat Dilatometer Conference, Washington D.C.: 275-280, 2006.

44. P. Monaco, S. Amoroso, S. Marchetti, D. Marchetti, G. Totani; S. Cola, P. Simonini, "Overconsolidation and Stiffness of Venice Lagoon Sands and Silts from SDMT and CPTU. J. Geotech. Geoenviron. Eng., ASCE, v. $140: 1$, p. $215-227,2014$.

45. P. Popielski, "The influence of deep foundations on urban environment", Publishing House of the Warsaw University of Technology, Environmental Engineering, Z. 61, 2012.

46. S. Rabarijoely, "The use of dilatometer test to determine the undrained shear strength of organic soils", Annals of Warsaw University of Life Sciences - SGGW, Land Reclam., 40, pp. 97-105. 2008.

47. S. Rabarijoely, K. Garbulewski, "Simultaneous interpretation of CPT/DMT tests to ground characterization", Proc. of the 18th Int. Conf. on Soil Mechanics and Geotech. Eng., Paris, Vol. 1, pp. 1337-1340, 2013.

48. Research Project (Grant Number 4 T07E 047 30) conducted by Building Research Institute in Warsaw, 2008.

49. P. K. Robertson, "Interpretation of cone penetration tests - unified approach", Can. Geotech. J. 46, 1337-1355, 2009.

50. P. K. Robertson, "Cone penetration test (CPT)-based soil behavior type (SBT) classification system - an update", Canadian Geotechnical Journal, 53: 1910-1927, 2016.

51. G. Sanglerat, "The penetrometr and soil exploration", Elsevier, Amsterdam, 1972.

52. S. Shibuya, H. Tanaka, "Estimate of Elastic Shear Modulus in Holocene Soil Deposits", Soils and Foundations, Vol. 36, No. 4, 45-55, 1996.

53. Z. Sikora, „Static penetration - methodology and aplication in geoengineering”, wyd. nauk-tech. Warszawa, 2006. In polish.

54. Standard: Eurocode 7 PN-EN 1997-2:2008: Geotechnical Design - Part 2: Ground investigation and testing.

55. M. Superczyńska, K. Józefiak, A. Zbiciak, "Numerical analysis of diaphragm wall model executed in Poznań clay formation applying selected FEM codes", Archives of Civil Engineering Vol. LXII, Issue 3: 207-224, 2016.

56. S. Oztoprak, M. D. Bolton, "Stiffness of sands through a laboratory test database", Géotechnique, Vol. 63 Issue 1, pp. 54-70, 2013.

57. H. Tanaka, M. Tanaka, „Characterization of Sandy Soils using CPT and DMT”, Soils and Foundations, Japanese Geot. Soc.,Vol. 38, 3: 55-65, 1998 .

58. A. Truty, K. Podleś, "Numerical model of flat dilatometer test in cohesionless soils", 4th Int. Symposium on Computational Geomechanics: ComGeo IV, Assisi, Italy, 144-145, 2018.

59. P. Vardanega, M. D. Bolton, "Practical methods to estimate the non-linear shear stiffness of fine grained soils", 5th Int. Symposium on Deformation Characteristics of GeomaterialsAt: Seoul, South KoreaVolume: 1, 372-379, 2011.

60. L. Wysokiński, T. Godlewski, M. Wszędyrówny-Nast, ” Regional corelations of geotechnical parameters on the basis of CPTU and DMT tests", Wyd. Uczel. UTB Bydgoszcz, Proc. of Conf., pp. 235-242, 2009. In polish.

61. J. Wierzbicki, "Evaluation of subsoil overconsolidation by means of in situ tests at aspect of irs origin", Rozprawy Naukowe nr 410. Wydawnictwo Uniwersytetu Przyrodniczego w Poznaniu, 2010. In polish.

62. M. Witowski, "Local Displacement Transducer with Miniature Position Encoder", Geotechnical Testing Journal, (in print), 2018. 


\section{LIST OF FIGURES AND TABLES:}

Fig. 1. Strain-dependent non-linearity of shear stiffness modulus in light of strain-levels associated with different structure-types and testing methods.

Rys. 1. Nieliniowość modułu ścinania w zależności od odkształceń na tle pracy wybranych konstrukcji i różnych metod badawczych.

Fig. 2. All results for different test sites for analyzed soils plotted on Marchetii's classification nomogram.

Rys. 2. Zestawienie wszystkich wyników uzyskanych na poligonach badawczych na tle nomogramu klasyfikacyjnego Marchettiego.

Fig. 3. DMT calibration curve obtained for Polish ground conditions.

Rys. 3. Krzywa kalibracja dla badania dylatometrem w warunkach gruntów polskich .

Fig. 4. Graph of the $\mathrm{G}_{\mathrm{DMT}} / \mathrm{G}_{0}$ (left) and $\mathrm{G}_{0} / \mathrm{M}_{\mathrm{DMT}}$ indicator (right) vs $\mathrm{K}_{\mathrm{D}}$ for chosen types of soils.

Rys.4. Wykres zależności pomiędzy $\mathrm{G}_{\mathrm{DMT}} / \mathrm{G}_{0}$ (z lewej) i $\mathrm{G}_{0} / \mathrm{M}_{\mathrm{DMT}}$ (z prawej) a $\mathrm{K}_{\mathrm{D}}$ dla wybranych typów gruntów.

Fig. 5. Shape of the normalized $G / G_{0}-\gamma$ degradation curve's range and values of $G_{D M T} / G_{0}-\gamma_{D_{M T}}$ based on the SDMT for OC clays (on left) and OC glacial tills (on right).

Rys. 5. Kształt znormalizowanego wykresu G/G $\mathrm{G}_{0}-\gamma$ oraz zakres wartości $\mathrm{G}_{\mathrm{DMT}} / \mathrm{G}_{0}-\gamma_{\mathrm{DMT}}$ uzyskanych z badań SDMT dla przekonsolidowanych iłów (z lewej) i glin zwałowych (z prawej).

Fig. 6. Reference stiffness degradation curve for OC soils (for clays on left and glacial tills on right) and range of in situ results from SDMT.

Rys. 6. Krzywe referencyjne degradacji podłoża dla gruntów przekonsolidowanych (iły z lewej, gliny zwałowe z prawej) oraz zakres wyników z badań SDMT.

Fig. 7. Proposition of the procedure of evaluation of stiffness degradation curves from in situ tests

Rys. 7. Propozycja procedury wyznaczania krzywych degradacji sztywności z badań polowych.

Tab. 1. The obtained coefficients on the basis of charts - proposals of empirical cone factors $(\alpha)$ to estimate modulus value $\left(\mathrm{E}_{\text {eod }}\right)$ for Polish grounds conditions, versus literature.

Tab. 1. Ustalone na podstawie uzyskanych zależności współczynniki - propozycja wartości empirycznej $(\alpha)$ do wyznaczania wartości modułu $\left(\mathrm{E}_{\text {eod }}\right)$ dla polskich warunków gruntowych na tle danych z literatury.

Tab. 2. Summary of basic properties for analyzed soils a) clays; b) glacial tills.

Tab. 2. Zestawienie podstawowych parametrów dla analizowanych gruntów a) iły, b) gliny zwałowe. 


\section{OCENA DEGRADACJI SZTYWNOŚCI Z BADAŃ POLOWYCH DLA RÓŻNYCH TYPÓW GRUNTÓW}

Słowa kluczowe: sztywność gruntu, badania polowe (in situ), referencyjne krzywe degradacji sztywności, dylatometr sejsmiczny, grunty przekonsolidowane.

\section{STResZCZenIE}

Coraz bardziej skomplikowane układy konstrukcyjne wymagają indywidualnego podejścia przy wyznaczaniu parametrów, za każdym razem uwzględniając i modelując już na etapie badań, późniejsze warunki współpracy z podłożem. Jak wykazały dane z literatury tematu oraz wyniki uzyskane z badań własnych, grunty charakteryzują się silną nieliniowością modułu w zależności od odkształcenia, zatem należy precyzyjnie dobierać metody badania podłoża, tzn. w zakresie ich „,zułości” pomiarowej, odpowiedniej dla danego typu konstrukcji budowlanych. Gdy nie są dostępne bezpośrednie pomiary, a metoda obliczeń projektowych wymaga określonych parametrów, wtedy rozwiązaniem pomocnym staje się poszukiwanie zależności korelacyjnych z poligonów badawczych i stosowanie procedur pozwalających na oszacowanie wymaganych parametrów (przy najmniej na etapie początkowych analiz). W artykule przedstawiono schematu postępowania w zakresie opisu i oceny sztywności podłoża na podstawie badań polowych (CPTU, DMT i SDMT) i opracowanych krzywych referencyjnych z badań laboratoryjnych (TRX) dla wybranych typów gruntów (iły i gliny). W oparciu o podany algorytm możliwe jest wyznaczenie wartości modułu $\mathrm{G}_{0}$ dla dowolnej wielkości strefy odkształcenia, stosując uzyskane z badań własnych zależności lokalne, w tym modele degradacji podłoża. 